\title{
Management of Leaf Spots or Tikka Disease of Groundnut (Passalora arachidicola \& Nothopassalora personata) through Systemic Fungicides
}

\author{
R. K. Sharma*, M. M. Patel and D. R. Patel \\ Agricultural Research Station, Sardarkrushinagar Dantiwada Agricultural University \\ Ladol, Mehsana, Gujarat, India - 384540 \\ *Corresponding author
}

\section{A B S T R A C T}

\begin{tabular}{l} 
Ke y w o r d s \\
Groundnut, Leaf \\
spot, Tikka, \\
Disease, \\
Management, \\
Systemic fungicide, \\
Tebuconazole, \\
Passalora \\
arachidicola and \\
Nothopassalora \\
personata \\
\hline Article Info \\
\hline $\begin{array}{l}\text { Accepted: } \\
\text { 04 March } 2020 \\
\text { Available Online: } \\
\text { 10 April } 2020\end{array}$ \\
\hline \hline
\end{tabular}

An experiment was carried out at Agricultural Research Station, Ladol to test the efficacy of some effective systemic fungicides viz. tebuconazole 50\%+trifloxystrobin $25 \%$ WG, difenconazole $25 \%$ EC, hexaconazole 5\% EC and tebuconazole $25.9 \%$ EC with their prefix concentrations against leaf spots or tikka disease of groundnut. A variant with no application of fungicide was used as a control. All the treatments reduced the disease intensity significantly as compared to untreated check. The per cent disease intensity was recorded periodically at 60,75 and 90 days after the sowing with consecutive three spray of fungicides (before and 7 days after spray) at 15 days interval and was found moderate to medium in range (13.72-44.84 per cent). The minimum disease intensity was recorded in the treatment $\mathrm{T}_{3}$ at $90 \mathrm{DAS}$ at applied after third spray ( 7 days after spray) with its PDI 24.35 per cent. After harvesting of the crop, the highest pod and haulm yield was also obtained from the plots treated with the same treatment $\mathrm{T}_{3}$ i.e. spraying of tebuconazole $50 \%$ +trifloxystrobin 25\% WG @ 0.25\% concentration (pod-2422 kg; haulm-3207 kg ha ${ }^{-1}$ ) followed by the treatments $T_{2}$ (pod-2407 kg; haulm-3178 kg ha ${ }^{-1}$ ) and $T_{7}$ (pod-2378 kg; haulm-3167 kg ha ${ }^{-1}$ ). Here, The efficacy of combination fungicide of triazole and strobilurin group, i.e. tebuconazole 50\%+trifloxystrobin 25\% WG @ $0.25 \%$ concentration was found very effective against early and late leaf spots of groundnut and increasing the pod as well as haulm yield also.

\section{Introduction}

Groundnut (Arachis hypogaea L.) is an important food (Leguminous \& Oilseed) crop having high content of protein and oil. Its seed is used as a source of cooking oil and in confectionary products for human consumption (Naab et al., 2005). After oil extraction, groundnut cake is obtained as a by-product which are mainly used as cattle feed and manure. It contains about 43-65 per cent protein and 6-20 per cent fat plus some B-group vitamins and micronutrients depending upon the method of extraction. India cultivates about 7.74 million hectares and produces 7.61 million tonnes of groundnut with average yield $1486 \mathrm{~kg} \mathrm{ha}^{-1}$ (Madhusudhana, 2013). 
The major groundnut producing states are viz. Gujarat, Andhra Pradesh, Rajasthan, Karnataka, Madhya Pradesh, Maharashtra, Tamil Nadu and Uttar Pradesh. Among these states, Gujarat having 20 lakh hectares area of groundnut with its total production of about 26 lakh tonnes annually (Anonymous, 2018; Gayathri, 2018).

Like any other economically important crop, groundnut is also susceptible to many diseases caused by fungi, bacteria, viruses and nematodes (Mayee, 1987). The majority of diseases are caused by fungi and several of them are yield reducers in certain regions and seasons (Mayee, 1995). Foliar fungal diseases causes severe damage during any stage of crop growth and yield losses over 25 per cent have been reported by Mayee and Datar (1988).

Leaf spot or Tikka disease is the most important foliar fungal disease of groundnut. Without foliar application of fungicides the losses in excess of 50 per cent of potential yield (Subrahmanyam et al., 1980; Ghuge et $a l .$, 1981). When it is associated with rust, the losses reached up to 70 per cent (Vidyasekaran, 1981). Groundnut is affected by early leaf spot (Passalora arachidicola (Hori) U. Braun), late leaf spot (Nothopassalora personata (Berk. \& Curtis) U. Braun, C. Nakash., Videira \& Crous) and rust (Puccinia arachidis Speg.) all over the world including India (Melouk et al., 1984; Subrahmanyam et al., 1985).

Previously the cercosporoid fungus, was known as early leaf spots (Cercospora arachidicola Hori.) and late leaf spot (Cecosporidium personatum Black \& Curt.) on the basis of morphological characters but now the fungus have new names on the basis of molecular studies and considered as early leaf spot (Passalora arachidicola (Hori) U. Braun), late leaf spot
Nothopassalora personata (Berk. \& Curtis) U. Braun, C. Nakash., Videira \& Crous). These fungi cause leaf spots damage to the plant by reducing the available photosynthetic area, by lesion formation, and by stimulating leaflet abscission. The disease occurs on all above ground parts of the plant, more severely on the leaves.

The leaf symptoms produced by the two pathogens can be easily distinguished by appearance; spot color and shapes (Fig. 1 and 2 ). Both the fungi produce lesions also on petiole, stem and pegs. The lesions caused by both species coalesce as infection develops and severely spotted leaves shed prematurely. The quality and yield of nuts are drastically reduced in case of severe infection. Prolonged high relative humidity for more than three days, low temperature $\left(\leq 20^{\circ} \mathrm{C}\right)$ with dew on leaf surface, heavy doses of nitrogen and phosphorus fertilizers and deficiency of magnesium in soil are the main reasons to increase disease potentiality.

The pathogen survives for a long period in the infected plant debris through conidia, dormant mycelium and perithecia in soil. The volunteer groundnut plants also harbour the pathogen. The primary infection is by ascospores or conidia from infected plant debris or infected seeds. The secondary spread is by windblown conidia. Rain splash also helps in the spread of conidia.

Perusal of literature indicated that the combined application fungicides and host resistance is quite effective in the management of foliar diseases and several fungicides have been identified and evaluated to management the leaf spot diseases at different places (Subrahmanyam et al., 1995 and Munda et al., 1997). Fungicides application can increase the genetic potential and yield reduction due to disease can be minimized. Systemic fungicides inhibit the 
spore germination and penetration of the pathogens, Therefore an experiment is conducting to investigate the performance of some systemic fungicides at different concentrations under this agro-climatic region which can reduce loss with effective and economic approach as spray scheduled.

\section{Materials and Methods}

An experiment was conducted at Agricultural Research Station, SDAU, Ladol in kharif 2019-20 with susceptible variety of groundnut G.G.-2. To study the comparative efficacy of some effective systemic fungicides along with the combination of Triazole and Strobilurin group against tikka disease of groundnut, the experiment was laid out in randomized block design with three replications having a gross plot size of $4.5 \mathrm{~m} \mathrm{X} 5.0 \mathrm{~m}$ and a net plot size of $3.6 \mathrm{~m} \mathrm{X} 4.6 \mathrm{~m}$ with spacing of $45 \mathrm{~cm} \mathrm{X} 10$ $\mathrm{cm}$. All the treatments each being comprised of 3 sprays were imposed after the appearance of the disease starting from 60 DAS till 90 DAS at 15 days interval. Observations of disease intensity were recorded from the appearance of the disease at 15 days interval (before and 7 days after spray) till 90 day after sowing (DAS) as per the 1-9 point scale for assessment of tikka leaf spot on groundnut explicated by Subrahmanyam et al., (1982 a, b).

The per cent disease intensity (PDI) was computed as per the formula suggested by Horsfall and Heuberger (1942).

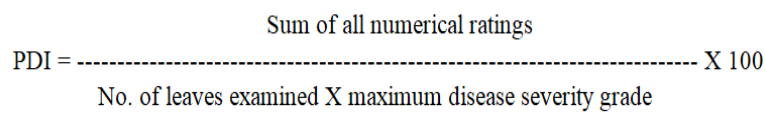

The per cent disease intensity data was arcsine transformed before analysis of variance (ANOVA). The data on yield parameter like pod and haulm yield was recorded after allowing pods to dry in sun for 10 days after the harvest.
All the data were statistically analyzed with using the standard procedure described by Gomez and Gomez (1986) and Indian NARS Statistical Computing Portal.

\section{Results and Discussion}

The data on PDI of leaf spots (early \& late) of groundnut was recorded periodically at 60,75 and 90 days after the sowing with consecutive three spray of fungicides (before and 7 days after spray) at 15 days interval and was found moderate to medium in range (13.72-44.84 per cent). It has also been found that in all the treatments, PDI increased with the age of the plants. The data on disease intensity revealed that all systemic fungicides tested reduced the disease intensity significantly with their prefix concentrations as compared to control.

Table 2 revealed that the disease initiation was very limited at 60 DAS before first spray and there was no statistical difference among the treatments. The minimum PDI was recorded at 60 DAS at 7 days after first spray in treatment $\mathrm{T}_{3}$ i.e. spraying of tebuconazole $50 \%+$ trifloxystrobin 25\% WG @ $0.25 \%$ $(14.06 \%)$ and it was found significantly less over rest of the treatments followed by the treatments $\mathrm{T}_{2}, \mathrm{~T}_{7}$ and $\mathrm{T}_{8}$. The same trends were found in the treatment $T_{3}$ at 75 and 90 DAS at applied after second and third spray (7 days after spray) with minimum PDI 18.53 and 24.35 per cent, respectively as compared to control.

After harvesting of the crop, the highest pod yield was obtained from the plots treated with treatment $\mathrm{T}_{3}$ i.e. spraying of tebuconazole $50 \%+$ trifloxystrobin 25\% WG @ $0.25 \%$ $\left(2422 \mathrm{~kg} \mathrm{ha}^{-1}\right)$ followed by the treatments $\mathrm{T}_{2}$, $\mathrm{T}_{7}, \mathrm{~T}_{8}$ and $\mathrm{T}_{1}(2407,2378,2243$ and $2207 \mathrm{~kg}$ $\mathrm{ha}^{-1}$ ) respectively. Similarly highest haulm yield was also recorded in the treatment $T_{3}$ $\left(3207 \mathrm{~kg} \mathrm{ha}^{-1}\right)$ but there was no significant difference found as compare to untreated check. 
Table.1 Field scale (1-9 point) for assessment of leaf spot or tikka on groundnut (after Subrahmanyam et al., 1982a, b)

\begin{tabular}{|l|c|}
\hline Leaf spot & Score \\
\hline No disease & 1 \\
\hline Few, small necrotic spots on older leaves & 2 \\
\hline Small spots, mainly on older leaves, sparse sporulation & 3 \\
\hline Many spots, mostly on lower and middle leaves, disease evident & 4 \\
\hline $\begin{array}{l}\text { Spots easily seen on lower and middle leaves, moderately sporulating, yellowing } \\
\text { and defoliation of some lower leaves }\end{array}$ & 5 \\
\hline As rating 5 but spots heavily sporulating & 6 \\
\hline $\begin{array}{l}\text { Disease easily seen from a distance; spots present all over the plant; lower and } \\
\text { middle leaves defoliating }\end{array}$ & 7 \\
\hline \begin{tabular}{l} 
As rating 7 but defoliation is more severe \\
\hline Plants severely affected, 50-100 \% defoliation
\end{tabular} & 8 \\
\hline
\end{tabular}

Table.2 Evaluation of some effective systemic fungicides against leaf spots or tikka disease of groundnut cv. G.G.-2

\begin{tabular}{|c|c|c|c|c|c|c|c|c|c|}
\hline \multirow{4}{*}{$\begin{array}{l}\text { Tr. } \\
\text { No. }\end{array}$} & \multirow[t]{4}{*}{ Treatment } & \multicolumn{6}{|c|}{ Percent Disease Intensity (PDI) } & \multirow{3}{*}{\multicolumn{2}{|c|}{$\underset{\left(\mathrm{kg} \mathrm{ha}^{-1}\right)}{\text { Yield }}$}} \\
\hline & & \multirow{2}{*}{\multicolumn{2}{|c|}{$\begin{array}{l}60 \text { DAS } \\
\text { First Spray }\end{array}$}} & \multirow{2}{*}{\multicolumn{2}{|c|}{$\begin{array}{c}75 \text { DAS } \\
\text { Second Spray }\end{array}$}} & \multirow{2}{*}{\multicolumn{2}{|c|}{$\begin{array}{c}90 \text { DAS } \\
\text { Third Spray }\end{array}$}} & & \\
\hline & & & & & & & & & \\
\hline & & Before & $\begin{array}{c}7 \\
\text { DASP }\end{array}$ & Before & $\begin{array}{c}7 \\
\text { DASP }\end{array}$ & Before & $\begin{array}{c}7 \\
\text { DASP }\end{array}$ & Pod & Haulm \\
\hline T1 & $\begin{array}{l}\text { Tebuconazole 50\% + } \\
\text { Trifloxystrobin 25\% WG @ 0.15\% }\end{array}$ & $\begin{array}{c}13.72 \\
(5.65)^{*}\end{array}$ & $\begin{array}{l}19.46 \\
(11.11)\end{array}$ & $\begin{array}{c}25.10 \\
(18.03)\end{array}$ & $\begin{array}{c}25.57 \\
(18.65)\end{array}$ & $\begin{array}{l}30.11 \\
(25.18)\end{array}$ & $\begin{array}{l}31.22 \\
(26.91)\end{array}$ & 2207 & 3141 \\
\hline T2 & $\begin{array}{l}\text { Tebuconazole 50\%+ } \\
\text { Trifloxystrobin 25\% WG @ 0.2\% }\end{array}$ & $\begin{array}{l}14.05 \\
(5.91)\end{array}$ & $\begin{array}{l}15.77 \\
(7.41)\end{array}$ & $\begin{array}{c}19.90 \\
(11.60)\end{array}$ & $\begin{array}{c}23.30 \\
(15.68)\end{array}$ & $\begin{array}{c}26.03 \\
(19.27)\end{array}$ & $\begin{array}{l}27.60 \\
(21.48)\end{array}$ & 2407 & 3178 \\
\hline T3 & $\begin{array}{l}\text { Tebuconazole } 50 \%+ \\
\text { Trifloxystrobin 25\% WG @ 0.25\% }\end{array}$ & $\begin{array}{l}13.77 \\
(5.68)\end{array}$ & $\begin{array}{l}14.06 \\
(5.92)\end{array}$ & $\begin{array}{l}17.32 \\
(8.88)\end{array}$ & $\begin{array}{c}18.53 \\
(10.12)\end{array}$ & $\begin{array}{c}23.30 \\
(15.67)\end{array}$ & $\begin{array}{c}24.35 \\
(17.03)\end{array}$ & 2422 & 3207 \\
\hline T4 & $\begin{array}{l}\text { Difenoconazole 25\% EC @ } \\
0.0187 \%\end{array}$ & $\begin{array}{l}14.11 \\
(5.96)\end{array}$ & $\begin{array}{c}23.98 \\
(16.54)\end{array}$ & $\begin{array}{c}30.59 \\
(25.92)\end{array}$ & $\begin{array}{l}31.55 \\
(27.40)\end{array}$ & $\begin{array}{c}37.11 \\
(36.42)\end{array}$ & $\begin{array}{c}38.05 \\
(38.02)\end{array}$ & 1831 & 2926 \\
\hline T5 & $\begin{array}{l}\text { Difenoconazole 25\% EC @ } \\
0.025 \%\end{array}$ & $\begin{array}{l}13.74 \\
(5.67)\end{array}$ & $\begin{array}{c}21.82 \\
(13.82)\end{array}$ & $\begin{array}{l}28.10 \\
(22.22)\end{array}$ & $\begin{array}{l}29.26 \\
(23.91)\end{array}$ & $\begin{array}{c}35.17 \\
(33.21)\end{array}$ & $\begin{array}{c}35.92 \\
(34.44)\end{array}$ & 1938 & 2941 \\
\hline T6 & $\begin{array}{l}\text { Difenoconazole } 25 \% \text { EC } \\
@ 0.031 \%\end{array}$ & $\begin{array}{l}14.05 \\
(5.91)\end{array}$ & $\begin{array}{c}21.40 \\
(13.33)\end{array}$ & $\begin{array}{l}27.85 \\
(21.85)\end{array}$ & $\begin{array}{c}28.78 \\
(23.21)\end{array}$ & $\begin{array}{l}30.67 \\
(26.04)\end{array}$ & $\begin{array}{c}32.65 \\
(29.13)\end{array}$ & 1948 & 2956 \\
\hline T7 & Hexaconazole 5\% EC @ 0.005\% & $\begin{array}{l}13.72 \\
(5.65)\end{array}$ & $\begin{array}{l}17.33 \\
(8.89)\end{array}$ & $\begin{array}{c}21.80 \\
(13.82)\end{array}$ & $\begin{array}{c}23.68 \\
(16.17)\end{array}$ & $\begin{array}{l}28.02 \\
(22.10)\end{array}$ & $\begin{array}{l}29.78 \\
(24.69)\end{array}$ & 2378 & 3167 \\
\hline T8 & Tebuconazole 25.9\% EC @ 0.05\% & $\begin{array}{l}13.70 \\
(5.64)\end{array}$ & $\begin{array}{c}18.99 \\
(10.62)\end{array}$ & $\begin{array}{c}23.79 \\
(16.29)\end{array}$ & $\begin{array}{c}25.02 \\
(17.90)\end{array}$ & $\begin{array}{c}29.04 \\
(23.58)\end{array}$ & $\begin{array}{l}30.35 \\
(25.55)\end{array}$ & 2243 & 3156 \\
\hline \multirow[t]{4}{*}{ T9 } & Untreated Control & $\begin{array}{l}13.86 \\
(5.76)\end{array}$ & $\begin{array}{c}25.28 \\
(18.27)\end{array}$ & $\begin{array}{c}34.04 \\
(31.36)\end{array}$ & $\begin{array}{c}35.46 \\
(33.70)\end{array}$ & $\begin{array}{c}42.39 \\
(45.48)\end{array}$ & $\begin{array}{c}44.84 \\
(49.75)\end{array}$ & 1726 & 2800 \\
\hline & S.Em. \pm & 0.53 & 0.45 & 0.49 & 0.52 & 0.38 & 0.52 & 125 & 169 \\
\hline & C.D $(P=0.05)$ at $5 \%$ & NS & 1.35 & 1.49 & 1.56 & 1.14 & 1.57 & 371 & 502 \\
\hline & C.V. & 6.59 & 3.90 & 3.36 & 3.34 & 2.09 & 2.74 & 11.34 & 10.66 \\
\hline
\end{tabular}

* Figures in the parenthesis are original values.

PDI = Per cent Disease Intensity; DAS = Day after sowing; DASP = Days after spraying 



Fig.1 Early leaf spot symptoms on leaves
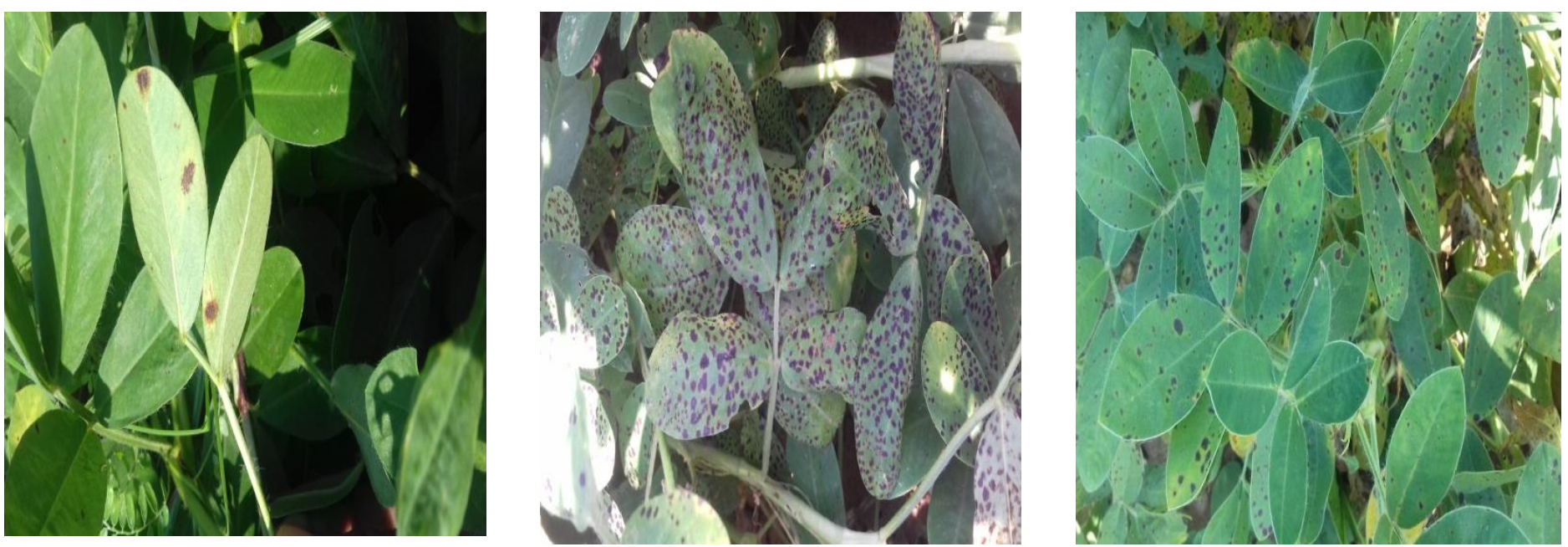

Fig.2 Late leaf spot symptoms on leaves

The present studies on efficacy of different systemic fungicides with their prefix concentrations against leaf spots or tikka disease of groundnut revealed that the combination of two different group of systemic fungicides (triazole and strobilurin)) i.e. tebuconazole 50\%+trifloxystrobin 25\% WG @ $0.25 \%$ was found very effective against early and late leaf spots of groundnut and increasing the pod as well as haulm yield also. Efficacy of tebuconazole against early and late leaf spots of groundnut has also been reported in Northern Ghana (Nutsugah et al., 2007).
They found when tebuconazole applied alone was effective in reducing leaf spot severity and it yielded significantly higher biomass and pod yields compared to most of the treatments. For management of late leaf spot by different fungicides, an experiment was carried out by Nath, et al., 2013. They tested three fungicides with their prefix concentrations in In vitro condition. Among three, Tebuconazole $(0.15 \%)$ gave best results and decrease per cent disease to $52.42 \%$ and increased yield up to $67 \%$ as compared to 37 $\%$ increase by tebuconazole $(0.10 \%)$. 
Mushrif et al., (2017) evaluated seven fungicides comprising of triazoles (difenoconazole, propiconazole, tebuconazole and bitertanol), dithiocarbamate (mancozeb), benzimidazole (carbendazim) and phthalimide (chlorothalonil) in vitro and in vivo against Cercospora arachidicola and Cercosporidium personatum, during kharif 2008-09 and 200910. They found, tebuconazole suppressed the germination at $50 \mathrm{ppm}$ of the spores of both the pathogens completely under in vitro conditions. The field experiments also showed that the tebuconazole ( 0.1 per cent) was effective in registering least disease severity in terms of percent disease intensity, 13.67 and 15.07 for 2009 and 2010 periods and highest pod yield, 2295.92 and 2551.02 $\mathrm{kg} \mathrm{ha}^{-1}$ and haulm yield, 2716.84 and 3066.22 $\mathrm{kg} \mathrm{ha}^{-1}$ respectively for 2009 and 2010 periods.

Among all three systemic fungicides used in present investigation, combination of two different group of systemic fungicides ((triazole and strobilurin)) i.e. tebuconazole $50 \%$ +trifloxystrobin 25\% WG was found very effective at $0.25 \%$ concentration against early and late leaf spots of groundnut and increasing the pod as well as haulm yield also. It may be due to its excellence in protective and curative type of nature and mode of action as well.

\section{References}

Anonymous 2018. Agricultural statistics at a glance-2018. Directorate of Economics and Statistics, Government of India. New Delhi, p.482. www.eands.dacnet.nic.in

Gayathri, J. 2018. A trend analysis of area, production and yield of groundnut in India. Shanlax International Journal of Economics. 6(3):15-21.

Ghuge, S. S., Mayee, C. D. and Godbole, G. M. 1981. Assessment of losses in peanut due to rust and Tikka leaf spots. Indian Phytopathology. 34(2):179-182.

Gomez, K. A. and Gomez, A. A. 1986. Statistical procedures for agriculture research. 2nd edition, John Wiley and Sons. pp.680.

Horsfall, J. G. and Henberger, J. W. 1942. Measuring magnitude of defoliation disease of tomatoes. Phytopathology. 32: 226-232.

Madhusudhana, B. 2013. A survey on area, production and productivity of groundnut crop in India. IOSR Journal of Economics and Finance (IOSR-JEF). 1(3): 01-07.

Mayee, C. D. 1987. Diseases of groundnut and their management. In: Plant protection in field crops, (Eds., M.V.N. Rao and S. Sitanantham), PPSI, Hyderabad. pp. 235-243.

Mayee, C. D. 1995. Current status and future approaches for management of groundnut disease in India. Indian Phytopathology. 48:389-401.

Mayee, C. D., Datar, V. V. 1988. Diseases of groundnut in the tropics. Review of Tropical Plant Plant pathology. 5:169198.

Melouk, H. A., Banks, D. J. and Fanous, M. A. 1984. Assessment of resistance to Cercospora arachidicola in peanut genotypes in field plots. Plant Disease. 68:395-397.

Munda, G. C., Hazarikam, U. K., Singh, R., Sharma, B. K. and Singh, J. 1997. Groundnut cultivation in north-eastern hills. Technical Bulletin. ICAR Research Complex for NEH Region, Umiam, Meghalaya, pp.32.

Mushrif, S. K., Manju, M. J., Shankarappa, T. H. and Nagaraju 2017. Comparative efficacy of fungicides against tikka disease of groundnut caused by Cercospora arachidicola and Cercosporidium personatum. The Ecoscan. 11(1\&2): 67-71. 
Naab, J. B., Tsigbey, F. K., Prasad, P. V. V., Boote, K. J., Bailey, J. E. and Brandenburg, R. L. 2005. Effects of sowing date and fungicide application on yield of early and late maturing groundnut cultivars grown under rainfed conditions in Ghana, Crop Protection. 24:325-332.

Nath, B. C., Singh, J. P., Srivastava, S. and Singh, R. B. 2013. Management of late leaf spot of groundnut by different fungicides and their impact on yield. Plant Pathology Journal. 12(2):85-91.

Nutsugah, S. K., Abudulai, M., Oti, B. C., Brandenburg, R. L. and Jordan, D. L. 2007. Management of leaf spot diseases of peanut with fungicides and local detergents in Ghana. Plant Pathology Journal. 6:248-253.

Subrahmanyam, P., Gibbons, R. W., Nigam, S. N. and Rao, V. R. 1982a. Screening methods and further sources of resistance to peanut rust. Peanut Science. 7:10-12.

Subrahmanyam, P., Mc Donald, D., Waliyar, F., Reddy, L. J., Nigam, S. N., Gibbons, R. W., Rao, V. R., Singh, A. K., Pandey, S., Reddy, P. M. and Subba
Rao, P. V. 1995. Screening methods and sources of resistance to rust and late leaf spot of groundnut. Information Bulletin No-47, ICRISAT, Andhra Pardesh, India, pp.20.

Subrahmanyam, P., McDonald, D., Gibbons, R. W., Nigam, S. N., and Nevill, D. J. 1982b. Resistance to rust and late leaf spot diseases in some genotypes of Arachis hypogaea. Peanut Science. 9:610.

Subrahmanyam, P., Mehan, V. K., Neveil, D. J. and McDonald, D. 1980. Research on fungal diseases of groundnut at ICRISAT, Proceeding ofthe International workshop on groundnut, $13-17^{\text {th }}$ October 1980, International Crops Research Institute for Semi-Arid Tropics, Patancheru, Andhra Pradesh. pp.193-199.

Subrahmanyam, P., Moss, J. P., McDonald, D., Subba Rao, P. V. and Rao, V. R. 1985. Resistance to Cercosporidium personatum leaf spot in wild Arachis species. Plant Disease. 69(11):951-54.

Vidyasekaran, P. 1981. Control of rust and tikka disease of groundnut. Indian Phytopathology. 34:20-23.

\section{How to cite this article:}

Sharma. R. K., M. M. Patel and Patel. D. R. 2020. Management of Leaf Spots or Tikka Disease of Groundnut (Passalora arachidicola \& Nothopassalora personata) through Systemic Fungicides. Int.J.Curr.Microbiol.App.Sci. 9(04): 259-265. doi: https://doi.org/10.20546/ijcmas.2020.904.031 